https: //doi.org/10.29013/AJT-19-11.12-45-47

Mazhidov Abdunabi Amonovich, Mardonova Saodat Muxammadjonovna, Muratova Gulsara Saidovna, Bukhara State University E-mail:sshav85@mail.ru

\title{
PRINTING AND TECHNICAL PROPERTIES OF COTTON FABRICS PRINTED BY THICKNING POLYMER COMPOSITIONS
}

\begin{abstract}
The article reveals thecolourstability of printed fabrics of modified and native starch. It also determines that the printing and technical properties, in particular, the degree of fixation of the dye and the intensity of the color, mostly depend on the nature of the thickener. Moreover, it has been established that the use of a new thickening composition for cloth printing leads to an improvement in the quality of printed fabrics.
\end{abstract}

Keywords: Colour stability, fabric, modification, dye, fixation, properties, thickener, quality.

Printing inks are highly viscous structured systems, and thickening is one of their main components [3]. It prevents the occurrence of undesirable reactions in the ink and counteracts the capillary forces of the substrate, ensuring the sharpness of the printed pattern [1-3].

The choice of products for thickening printing inks is one of the most important problems in the field of printing textile materials.

To achieve the best results, thickeners imparting a high viscosity to the paste paint should be used, as this will make it easier to subsequently wash the thickener from the fabric, it should also have such a color and chemical properties that would not preclude obtaining a pure color and color development [4].

Most natural thickeners used in the textile industry are polysaccharides. In terms of bulk of use, more than $90 \%$ of the natural thickeners are various starches and products of their modification [5].

The use of thickeners based on sodium alginate is more attractive, but their high cost due to the limited production of raw materials, inhibits their widespread implementation [7-8].

Today various methods for the modification and improvement of the printing and technical properties of starch thickenershave been proposed. New technological methods of chemical modification have been developed, and preparations have been created for the modification of starch directly in the conditions of textile enterprises. The main idea of the developed technological methods is the introduction of functional polymer compounds with carboxymethyl cellulose of natureinto hot starch paste, capable of adsorbing colloidal starch particles, preventing their aggregation, due to which the necessary rheological properties of the obtained product are achieved. To modify the starch in this way, the preparationcalled Printactivewas developed, which imparts a negative electrokinetic potential to colloidal starch particles, and therefore, to a lesser extent than unmodified thickener, forms covalent bonds with active dyes.

Chemically modified starch-based thickeners were tested in the printing of cotton fabrics with active dyes, the results of which are presented in Table 1.

Data presented in Table 1 show the replacement of common thickeners with chemically modified starch leads to a significant increase in the degree of colour fixation and the color intensity; reduce the stiffness of the printed fabric and improvement of the strength indicators of patterned colours of textile. 
Table 1.- The impact of the nature of the thickener and the methods of its modification on the coloristic properties of cotton fabrics, printed by ostazine bright red active dyes

\begin{tabular}{|c|c|c|c|c|c|c|c|}
\hline \multirow[b]{2}{*}{$\begin{array}{l}\text { Name of the } \\
\text { thickener }\end{array}$} & \multirow{2}{*}{$\begin{array}{c}\text { Method of } \\
\text { modifica- } \\
\text { tion }\end{array}$} & \multirow{2}{*}{\begin{tabular}{|l|} 
Thickener \\
concentra- \\
tion gr/kg
\end{tabular}} & \multirow{2}{*}{$\begin{array}{c}\text { Colour } \\
\text { intensity, } \\
\text { K/S }\end{array}$} & \multicolumn{3}{|c|}{ Colour stability, Mark } & \multirow{2}{*}{$\begin{array}{r}\text { Fixation de- } \\
\text { gree of ac- } \\
\text { tive dyes,\% } \\
\end{array}$} \\
\hline & & & & Washability & $\begin{array}{c}\text { Perspira- } \\
\text { tion }\end{array}$ & Dryness & \\
\hline Starch & Unmodified & 80 & 14,2 & $4 / 4 / 4$ & $4 / 4 / 4$ & 5 & 72.6 \\
\hline $\begin{array}{l}\text { Starch com- } \\
\text { position }\end{array}$ & Bare & 50 & 23.8 & $5 / 5 / 5$ & $5 / 4 / 5$ & 5 & 87.4 \\
\hline
\end{tabular}

Table 2. - Printing and technological properties of alginate, modified and native starch in cloth printing

\begin{tabular}{|l|c|c|c|c|c|c|}
\hline \multirow{2}{*}{\multicolumn{1}{|c|}{ Dye }} & \multicolumn{2}{|c|}{ Fixation degree of active dye.\% } & \multicolumn{3}{c|}{ Colour intensity. K/S } \\
\cline { 2 - 7 } & $\begin{array}{c}\text { Algi- } \\
\text { nate }\end{array}$ & $\begin{array}{c}\text { Modified } \\
\text { starch }\end{array}$ & $\begin{array}{c}\text { Native } \\
\text { starch }\end{array}$ & Alginate & $\begin{array}{c}\text { Modifies } \\
\text { starch }\end{array}$ & Native starch \\
\hline Vatb right green & 87.4 & 85.3 & 72.6 & 14.26 & 12.87 & 10.28 \\
\hline $\begin{array}{l}\text { Procion bright } \\
\text { orange }\end{array}$ & 85.3 & 84.6 & 71.2 & 12.16 & 11.84 & 7.65 \\
\hline Cibacroneb right red & 91.6 & 89.4 & 81.2 & 16.43 & 15.75 & 12.16 \\
\hline Remazolb right red & 93.2 & 91.6 & 82.3 & 14.74 & 14.22 & 9.65 \\
\hline
\end{tabular}

One of the main indicators of printed fabrics is the colour stability, i.e. their washing out capacity. In this regard, further studies are aimed at determining the amount of dye in the washing trough, itsfixation on the fiber and non-fixation on the fabric. The samples underwent thermo fixation and steaming processes after printing, and the capacity of washabilityof the dye was determined depending on the temperature, duration of washing, and type of dye. The research results are presented in Table 3.

Table 3. - Dependence of the degree of fixation of dyes and their washability out capacity on the type of thickener

\begin{tabular}{|c|c|c|c|c|c|c|c|}
\hline \multirow[b]{3}{*}{ Thickeners } & \multirow{3}{*}{$\begin{array}{l}\text { Tempera- } \\
\text { ture of } \\
\text { washing } \\
\text { trough, } \\
{ }^{\circ} \mathrm{C}\end{array}$} & \multicolumn{6}{|c|}{ Amount of the dye,\% } \\
\hline & & \multicolumn{3}{|c|}{ Active bright purple $4 K$} & \multicolumn{3}{|c|}{ Active bright red 5SX } \\
\hline & & $\begin{array}{l}\text { In } \\
\text { washing } \\
\text { trough }\end{array}$ & $\begin{array}{l}\text { Fixed } \\
\text { on the } \\
\text { fabric }\end{array}$ & $\begin{array}{c}\text { Non-fixed on } \\
\text { the fiber and } \\
\text { remained on } \\
\text { the fabric }\end{array}$ & $\begin{array}{l}\text { In wash- } \\
\text { ing } \\
\text { trough }\end{array}$ & $\begin{array}{l}\text { Fixed } \\
\text { on the } \\
\text { fabric }\end{array}$ & $\begin{array}{l}\text { Non-fixed on } \\
\text { the fiber and } \\
\text { remained on } \\
\text { the fabric }\end{array}$ \\
\hline Maize starch & 80 & 18.4 & 50.2 & 31.4 & 19.5 & 53.7 & 26.3 \\
\hline $\begin{array}{l}\text { Starch oxidizedwith- } \\
\text { manganoussulphate }\end{array}$ & 80 & 11.9 & 71.6 & 17.5 & 11.3 & 73.0 & 15.7 \\
\hline $\begin{array}{l}\text { Starch modified with } \\
\text { carboxymethyl cellu- } \\
\text { lose and sericin }\end{array}$ & 80 & 8.2 & 72.3 & 19.5 & 9.3 & 74.3 & 16.4 \\
\hline
\end{tabular}

As can be seen from the data in (Table 3), the modified starches which are obtained by oxidafixation of the dye with fiber thickeners made of tion using manganoussulphate and modified car- 
boxymethyl cellulose and sericin is approximately the same and it is $25 \%$ higher than ordinary starch thickening. When comparing printed formulations with ordinary starch and modified one, in the third case, not only the degree of fixation is greater, but also the amount of nonfixed dye remaining on the fabric is reduced, which helps increase the color stability to wet treatments.

Thus, as a result of evaluating the effectiveness of the developed thickener composition, it was found that the use of new thickening compositions improves the quality of cloth printing, increases the environmental friendly textile materials and reduces the material and resource intensity of cloth printing processes by 1.5 times.

\section{Conclusion}

1. New water-soluble polymer compositions have been pioneered as a thickener for printing cotton fabrics on the basis of starch, carboxymethyl cellulose and sericin and their basic physical and mechanical properties have been thoroughly studied.

2. It was shown that the viscosity of the solution of the thickening compositions mainly depends on the concentration of the components and the time for modification, where an increase in viscosity is observed in the case of using modified starch. It was noted that the developed polymer thickening ingredients based on starch, carboxymethyl cellulose and sericin have good thixotropy and are stable for long-term storage.

\section{References}

1. Kozlova O.V., Pryajnikova V. G., Odinsova O. I. and others. Механохимические технололгии получения модифицированных крахмальных загусток.Journal Аиректор Россия Аегпромбизнес. 2001.- № 4.P. 60-64.

2. Ikhtiyarova G. A., Yariev O.M., Mavlonov B. A., Khaydarov A.А. О процессах омыления акримовой эмульсии с целью получения загустителя Амя печатания ткани Узб. хим.журн. 2002. - № 3.- Р. 77-81.

3. Amonov M. R., Ikhtiyarova G. A., Yariev O. M., Ravshanov K. А. Загустки на основе природных и синтетических полимерных композиций Аля печатания тканей Узб.хим. журн. 2002.- № 4.P. 71-77.

4. Ibragimova F. B., Amonov M.R., Ikhtiyarova G.A. Оценка влияния сродства композиции загустки на предел текучести и фиксации печатной краски./ / Пцастические массы.- М., 2002.- № 10.- 42 p.

5. Yariev O.M., Ibragimova F. B., Amonov M. R., Sodikova S. Sh. Полимерная композиция на основе реакции поликонденсации полифосфата калия с производными $a, \gamma$ - дигалоиАгиАринглицерина / Журн. Уз. хим. - № 5. 2000. - Р. 37-39.

6. Nazarov S.I., Amonova Kh.I., Amonov M.R., Ravshanova K.А. Печатно-технические свойства композиций на основе крахмала модифицированного с фосфатными соединениями // Журнал Композиционные материалы. - Tashkent, 2008. - № 2. - P. 36-39.

7. Nazarov S. I., Yariev O. M., Amonov M. R., Nazarov N. М. Применение фосфатного крахмала в качестве загустителя печатных красок // Journal Проблемы текстиля. - Tashkent, 2008. - 2. - P. 67-71.

8. Nazarov S. I., Yariev O. M., Nazarov I. I., Ravshanov K. А. Модифицирование крахмала дмя применения его при печатании тканей активными краситемями // Uzbekchemicaljournal. - Tashkent, 2009. №2. - P. 57-60. 